\title{
Defective Production of IL-18 and IL-12 by Cord Blood Mononuclear Cells Influences the T Helper-1 Interferon Gamma Response to Group B Streptococci
}

\author{
TIMOTHY R. LA PINE, JOANNA L. JOYNER, NANCY H. AUGUSTINE, SPENCER D. KWAK, AND \\ HARRY R. HILL
}

\begin{abstract}
Departments of Pathology [J.L.J., N.H.A., S.D.K., H.R.H.], Pediatrics [H.R.H., T.R.L.], and Medicine [H.R.H.], University of Utah School of Medicine, Salt Lake City, Utah 84132, U.S.A.; and the ARUP Institute for Clinical and Experimental Pathology, Salt Lake City, Utah 84108, U.S.A
\end{abstract} \begin{abstract}
ABS
Human neonates are uniquely susceptible to group B strep-
tococcal (GBS) infections. We have shown that neonatal mixed mononuclear cells have a deficiency in the production of the $\mathrm{T}$ helper-1 (Th-1) cytokine, interferon gamma (IFN- $\gamma$ ), and that incubation of neonatal neutrophils with recombinant IFN- $\gamma$ corrects these neutrophil defects. IL-12 and the more recently described IL-18 are also Th- 1 type cytokines that are able to induce the production of IFN- $\gamma$ in the presence of bacteria and bacterial products. We examine the ability of GBS to induce the production of IFN- $\gamma$, IL-18, and IL-12 by cord blood mixed mononuclear cells and compared these results with the IFN- $\gamma$, IL-18, and IL-12 response of mixed mononuclear cells from adult blood. We demonstrate that cord blood mixed mononuclear cells produced significantly less IFN- $\gamma$, IL-18, and IL-12 in response to GBS compared with mixed mononuclear cells from adults. Cord blood mixed mononuclear cells' production of
\end{abstract}

IFN- $\gamma$ is enhanced by added recombinant IL-18 and IL-12. The maximal cord blood cell production of IFN- $\gamma$, in response to GBS, is achieved by priming the cells with both IL-18 and IL-12. We conclude that neonatal mixed mononuclear cells exhibit deficiencies in three main Th-1 type cytokine responses, IFN- $\gamma$, IL-12, and IL-18. This combined Th-1 type cytokine deficiency may contribute to the enhanced susceptibility of the human neonate to GBS and other microbial infections. (Pediatr Res 54: 276-281, 2003)
GBS, group B streptococci
Abbreviations
Th-1, T helper-1
IFN- $\boldsymbol{\gamma}$, interferon gamma
PMNL, polymorphonuclear leukocytes

IL-18 is a recently described member of the IL- 1 cytokine family, which was initially defined as IFN- $\gamma$-inducing factor (1). IL-18 gene expression and/or protein secretion has been observed in macrophages (2), dendritic cells (3), mononuclear cells (4), keratinocytes (5), chondrocytes (6), pituitary and adrenal cells (7), astrocytes and microglia (8), and intestinal epithelial cells (9). Studies have elucidated a broad array of effector functions implicating IL-18 as an important regulator of both innate and acquired immune responses $(10,11)$. In animals, IL-18 contributes to protective immunity against a

Received June 27, 2002; accepted February 24, 2003.

Correspondence: Harry R. Hill, Department of Pathology, University of Utah School of Medicine, 50 North Medical Dr., Rm. 5B114, Salt Lake City, UT 84132, U.S.A.; e-mail: Harry.Hill@path.utah.edu

Supported, in part, by U.S. Public Health Service Grant AI-13150 and NIAID Contract N01-AO-22749.

Presented, in part, at the annual meetings of the Society for Pediatric Research and the American Pediatric Society, Baltimore, MD, May 2002.

DOI: 10.1203/01.PDR.0000072515.10652.87 variety of pathogens, including Cryptococcus, Leishmania, Staphylococcus, Salmonella, and Mycobacteria (12-15).

IL-12 is also an integral immune regulator, which promotes Th-1 responses while suppressing Th-2 responses $(16,17)$. IL-12 is primarily produced by macrophages and dendritic cells and has been shown to induce the production of IFN- $\gamma$ by $\mathrm{T}$ cells and natural killer (NK) cells (18). Recent studies have focused on the interaction between IL-18 and IL-12 in certain inflammatory responses. In Th-1 immune responses, IL-18 and IL-12 are important cytokines that may synergistically stimulate IFN- $\gamma$ production and enhance NK and T cell-mediated cytotoxicity (19). Recent studies implicate the interaction of these Th- 1 cytokines in the development of autoimmune diseases and suggest that regulating their function may be therapeutically beneficial $(20,21)$.

Early-onset GBS infections in neonates often lead to sepsis and severe septic shock, with an approximate 5-15\% mortality rate (22-24). Abnormalities observed in the neonatal immune 
system, likely predisposing neonates to GBS infection include type-specific opsonic antibody deficiency (25) and defective PMNL chemotaxis (26). The depressed production of the Th-1 cytokine, IFN- $\gamma$, by human neonates probably contributes to their increased susceptibility to bacterial infections (27-29). We have also shown that recombinant human interferon gamma (rIFN- $\gamma$ ) can correct these defects and enhance the activation and movement of neonatal PMNL (30). In this study, we examine the ability of cord and adult blood mixed mononuclear cells to produce the Th- 1 cytokines IFN- $\gamma$ and IL-18 in response to GBS. We also describe the effect of IL-18 and IL-12 on GBS-stimulated production of IFN- $\gamma$ with and without $\mathrm{MAb}$ to IL-18 or IL-12 to determine their combined influence, if any, on the IFN- $\gamma$ response to GBS.

\section{MATERIALS AND METHODS}

Leukocyte preparation. Umbilical cord blood, obtained after normal term deliveries, and whole blood obtained from healthy adult volunteers was collected in tubes containing acid citrate dextrose solution A (Becton Dickinson, Franklin Lakes, NJ, U.S.A.), and processed within $18 \mathrm{~h}$ of delivery. Blood was diluted with Hanks balanced salt solution (1 vol/2 vol blood) (HBSS; BioWhittaker, Walkersville, MD, U.S.A.), and mixed mononuclear cells were separated by density gradient centrifugation on Ficoll-Paque Plus separation media (Amersham Pharmacia Biotech, Piscataway, NJ, U.S.A.). The mononuclear cell layer was removed, washed twice with HBSS, and adjusted to a concentration of $1.0 \times 10^{6} / \mathrm{mL}$ in RPMI 1640 medium with $2 \mathrm{mM}$ L-glutamine, $0.35 \mathrm{mM}$ HEPES buffer, $0.05 \mathrm{mg} / \mathrm{mL}$ gentamicin (all from BioWhittaker), and 10\% heat-inactivated normal human serum (North American Biologic Institute, Miami, FL, U.S.A.). Cells were incubated at $37^{\circ} \mathrm{C}$ with added $5 \%$ $\mathrm{CO}_{2}$ with IL-12 and IL-18 (R \& D Systems, Minneapolis, MN,
U.S.A.) both individually and combined for 24,48 , and $120 \mathrm{~h}$ with GBS. In the priming studies, the mixed mononuclear cells were preincubated with IL-12 and/or IL-18 for $30 \mathrm{~min}$ at $37^{\circ} \mathrm{C}$. GBS was then added along with IL-12 and/or IL-18 for an additional $24 \mathrm{~h}$.

Bacterial strains. COH-1, an encapsulated type III GBS strain, isolated from a patient with GBS infection (provided by Craig Rubens, University of Washington, Seattle, WA, U.S.A.) was grown overnight in Todd Hewitt broth (Difco, Detroit, MI, U.S.A.) at $37^{\circ} \mathrm{C}$. Bacteria were washed with PBS and the concentration was adjusted to an OD of 0.9 at $620 \mathrm{~nm}$ wavelength $\left(\sim 5.0 \times 10^{8} \mathrm{cfu} / \mathrm{mL}\right)$. Aliquots of bacteria were heat inactivated at $56^{\circ} \mathrm{C}$ for $1 \mathrm{~h}$ and stored at $-70^{\circ} \mathrm{C}$.

\section{ELISA}

The tissue culture supernatants were assayed for IFN- $\gamma$, IL-12, and IL-18 protein by ELISA (Immunotech, Westbrook, ME, U.S.A.). Duplicate determinations were done in each assay. Data were analyzed by unpaired $t$ test.

Institutional review board approval was obtained for the proposed studies and appropriate informed consent was obtained.

\section{RESULTS}

GBS in concentrations of $1 \times 10^{6}$ to $1 \times 10^{7} / \mathrm{mL}$ induced IL-18 production by cord blood mixed mononuclear cells and adult blood cells after $24 \mathrm{~h}$ incubation (Fig. 1). This response peaked at a GBS concentration of $1 \times 10^{6} / \mathrm{mL}$. At this concentration, there was a significant difference in IL-18 production between cord and adult blood mixed mononuclear cells ( $p$ $<0.007)$. The time course of appearance of IL-18 after exposure of mixed mononuclear cells from cord and adult blood to

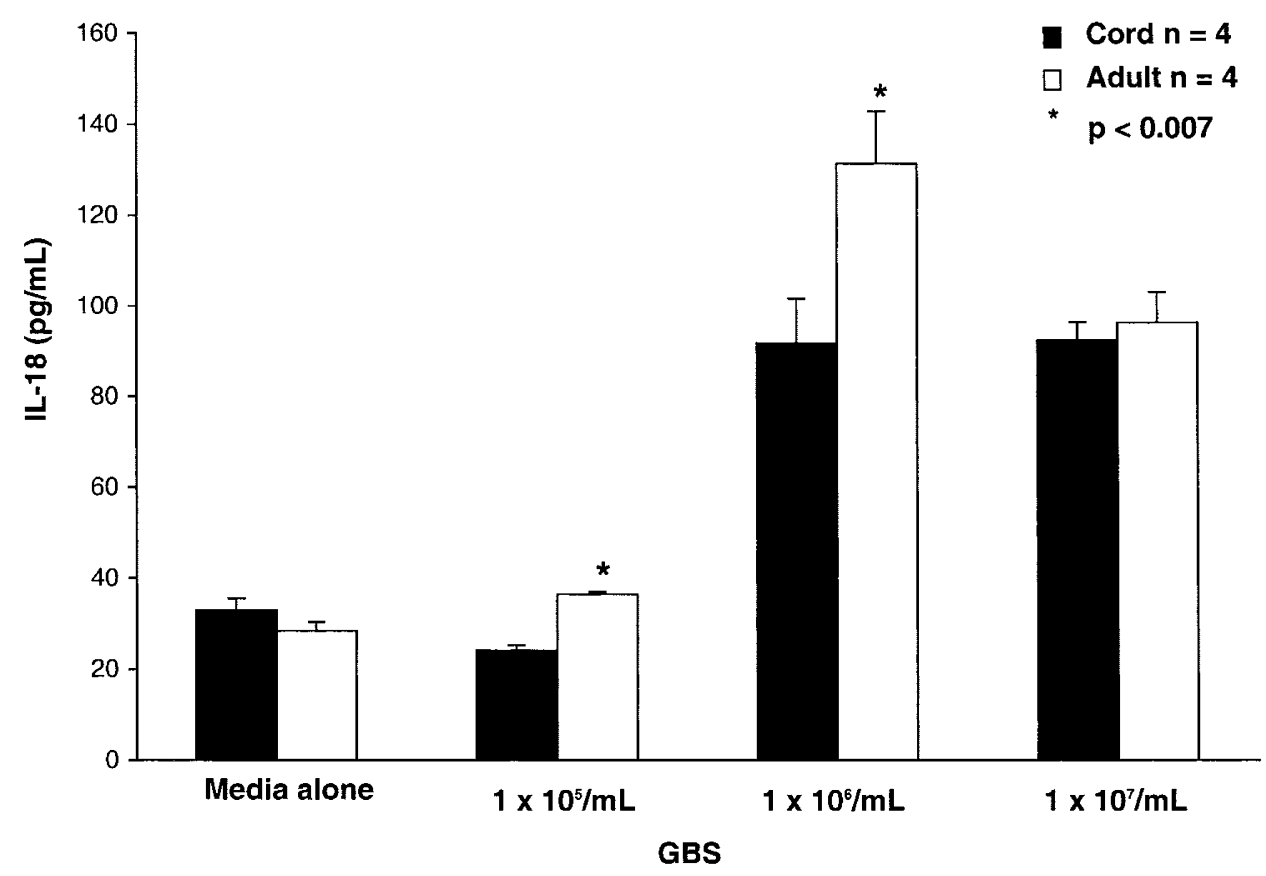

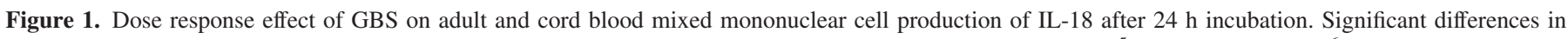
IL-18 production between cord and adult blood cell preparations are observed at GBS concentrations of $1 \times 10^{5} \mathrm{cfu} / \mathrm{mL}$ and $1 \times 10^{6} \mathrm{cfu} / \mathrm{mL}(p<0.07)$. 


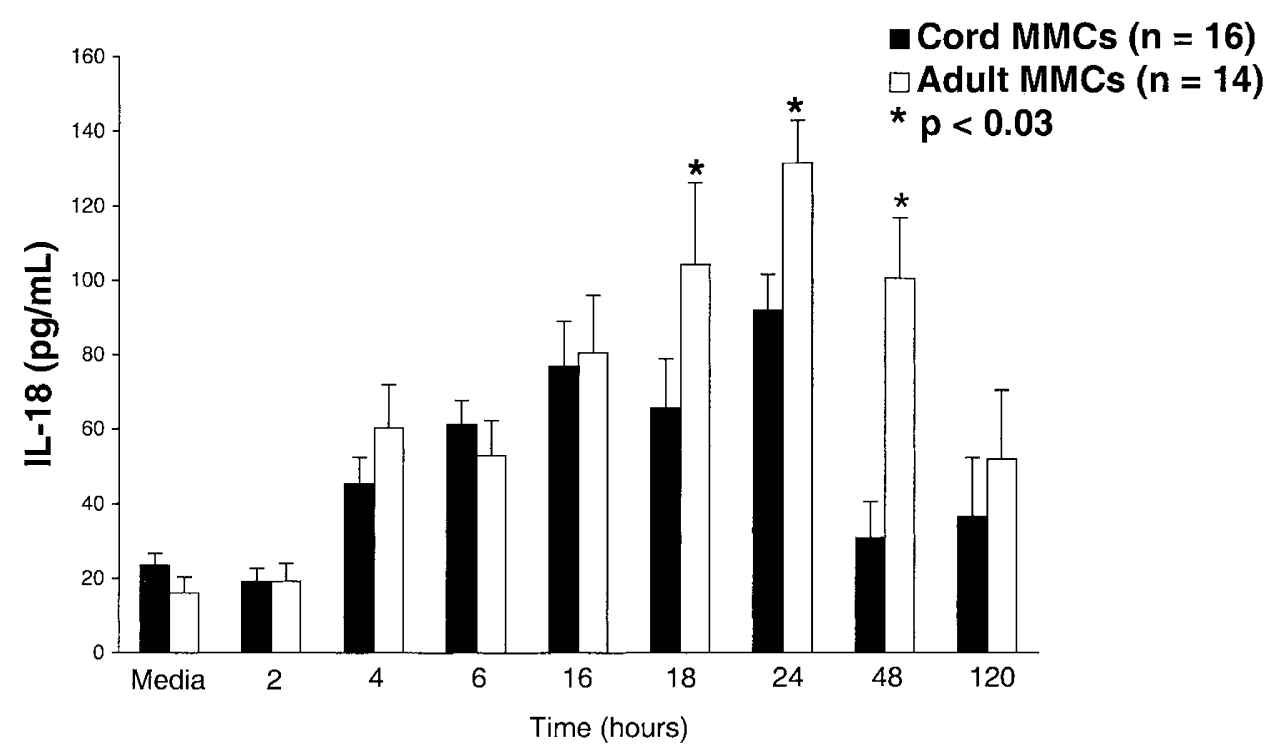

Figure 2. Time course production of IL-18 by cord and adult blood mixed mononuclear cells in response to GBS (10 $/ \mathrm{mL})$. Significant differences between cord and adult mixed mononuclear cell production of IL-18 in response to GBS are observed at 18, 24, and $48 \mathrm{~h}(p<0.03)$.

$1 \times 10^{6} / \mathrm{mL}$ GBS is shown in Figure 2. The response was detectable after $4 \mathrm{~h}$ and reached a peak at $24 \mathrm{~h}$, declining somewhat thereafter, especially in cord blood mixed mononuclear cells (Fig. 2). There was a statistically significant difference between IL-18 production by cord and adult blood mixed mononuclear cells observed at 18,24 , and $48 \mathrm{~h}(p<0.03)$. All additional experiments were carried out after $24 \mathrm{~h}$ incubation of the mononuclear cells with GBS with, and without, added cytokines.

Examining the effects of IL-18 (100 ng/mL) with and without anti-IL-18 MAb on the IFN- $\gamma$ response to GBS with mixed mononuclear cells from adult blood, we found that IL-18 (100 $\mathrm{ng} / \mathrm{mL}$ ) alone had no effect on mixed mononuclear cell production of IFN- $\gamma$ at $24 \mathrm{~h}$ (Fig. 3). It did, however, significantly increase IFN- $\gamma$ production by mixed mononuclear cells in response to GBS $(p<0.01)$. The addition of anti-IL-18 MAb completely blocked the added IL-18 enhanced response to GBS and actually lowered the total IFN- $\gamma$ production below that seen with GBS alone. This suggests that the antibody may be blocking an effect of endogenous IL-18 production as well as the added IL-18. Addition of anti-IL-18 antibody alone had no effect on mononuclear cell production of IFN- $\gamma$ (data not shown)

We next determined the effect of anti-IL-12 MAb on the IFN- $\gamma$ response of adult mixed mononuclear cells to GBS because IL-18 and IL-12 may act in concert, or synergistically, to enhance IFN- $\gamma$ production. This antibody alone had no effect on mononuclear cell production of IFN- $\gamma$ (data not shown).

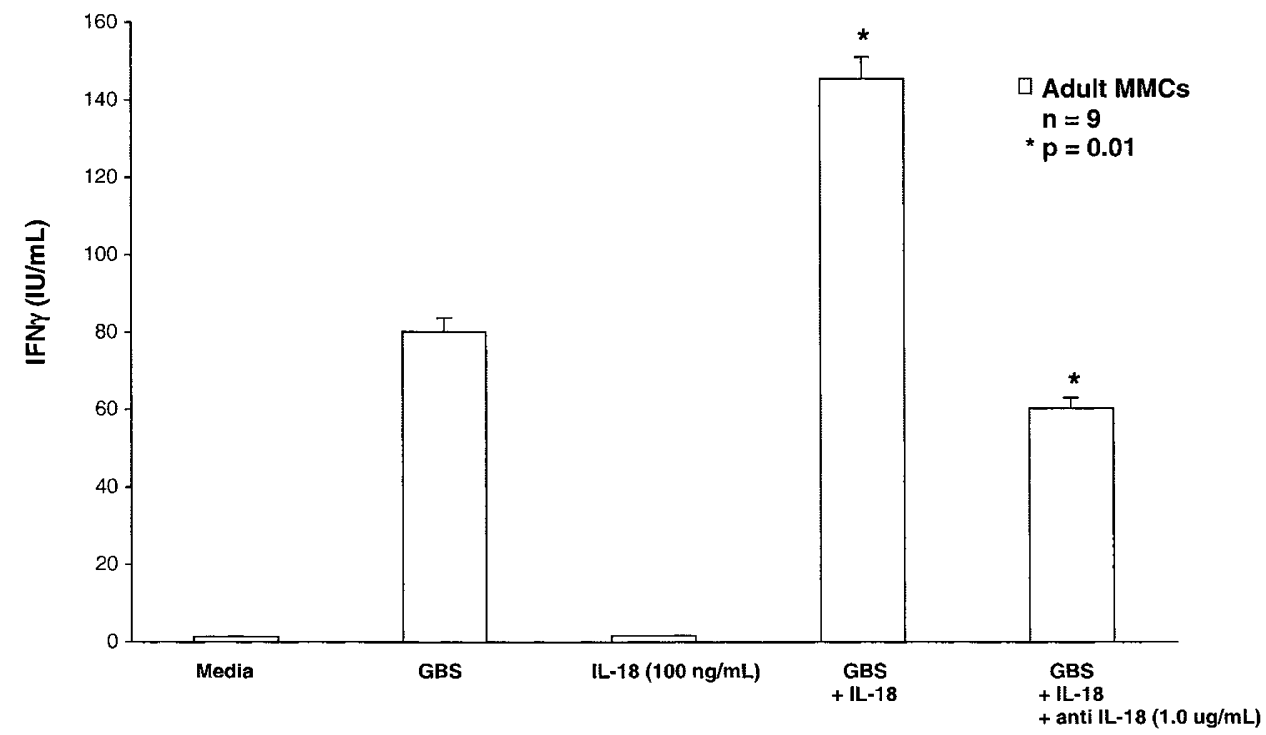

Figure 3. The effects of IL-18 (100 ng/mL) with and without anti-IL-18 MAb $(1.0 \mu \mathrm{g} / \mathrm{mL})$ on IFN- $\gamma$ production after $24 \mathrm{~h}$ incubation with GBS $\left(10^{6} / \mathrm{mL}\right)$. IL- 18 alone has no effect on IFN- $\gamma$ production but significantly increases IFN- $\gamma$ production in response to GBS. The addition of anti-IL-18 MAb (1.0 $\mu \mathrm{g} / \mathrm{mL})$ completely blocks the IL-18 response to GBS $(n=9)$. No effect on IFN- $\gamma$ production was observed with anti-IL-18 antibody alone (data not shown). 
The addition of anti-IL-12 depressed the IFN- $\gamma$ response to IL-18 and GBS (Fig. 4). IL-12 has been reported to have an effect to up-regulate IL-18 receptors on mixed mononuclear cells so that endogenous concentrations of this cytokine are necessary to have an optimal IL-18 response (31). It is likely that the anti-IL-12 may have blocked endogenous IL-12 production by mixed mononuclear cells in response to GBS in this experiment, thereby lowering the response to the added IL- 18 . Similarly, we examined the effect of anti-IL-18 antibody on IFN- $\gamma$ production by IL-12. The addition of anti-IL-18 antibody suppressed the GBS, IL-12, IFN- $\gamma$ response, but the decrease was not statistically significant ( $p=0.06$; Fig. 5).

Figure 6 illustrates the effects of IL-18 and IL-12 alone on IFN- $\gamma$ production by mixed mononuclear cells obtained from cord blood in response to GBS. As we have previously reported, the IFN- $\gamma$ response to GBS is quite low by cord blood mixed mononuclear cells. Addition of both recombinant IL-12 $(1.0 \mathrm{U} / \mathrm{mL})$ and IL-18 $(100 \mathrm{ng} / \mathrm{mL})$ significantly increased the response to GBS $(p<0.0001)$.

Because IL-18 and IL-12 individually can enhance IFN- $\gamma$ production by cord blood mixed mononuclear cells in response to GBS, we examined the combined effects of both cytokines together followed by priming of cord blood mixed mononuclear cells with either IL-18 and/or IL-12. Samples were primed for 30 min by incubation with either IL-18 and/or IL-12 before GBS exposure and then stimulated for $24 \mathrm{~h}$ with the organisms. As shown (Fig. 6), addition of either IL-12 and/or IL-18 to GBS-stimulated cord blood mixed mononuclear cell cultures enhanced IFN- $\gamma$ production significantly above that of GBS-stimulated cells alone $(p<0.0001)$. Priming with either IL-18 or IL-12 alone 30 min before GBS exposure with added IL-18 or IL-12 does not induce IFN- $\gamma$ production above that of unprimed cord blood mixed mononuclear cells exposed to both cytokines simultaneously. In contrast, priming mixed mononuclear cells from cord blood with IL-18 in combination with IL-12 enhances the GBS-stimulated production of IFN- $\gamma$ above that of mononuclear cells exposed to GBS in the presence of added IL-12 and IL-18 $(p<0.001)$. Thus, priming with both cytokines for $30 \mathrm{~min}$ before GBS exposure leads to optimal cord blood cell IFN- $\gamma$ responses.

\section{DISCUSSION}

Mixed mononuclear cells from cord blood produced significantly smaller quantities of IFN- $\gamma$, IL-12 (29), and IL-18 in response to GBS compared with stimulated mixed mononuclear cells from adult blood. We acknowledge that the use of mixed mononuclear cells, which likely reflects a more physiologic milieu, may contain cellular elements or products that may influence the GBS induction of the Th- 1 cytokines (IFN- $\gamma$, IL-12, and IL-18) between cord and adult cells. Nevertheless, our findings concerning GBS, an important neonatal pathogen, agree with those of Bryson and co-workers (27) and Wilson et al. (28), who reported neonatal deficiencies in IFN- $\gamma$ production by mixed mononuclear cells in response to mitogens. This deficiency in neonatal IFN- $\gamma$ production may be attributed, in part, to the developmental immaturity of neonatal T-lymphocyte populations. We suggest that, in addition to lymphocyte immaturity, other yet-to-be-described abnormalities in IL-18, IL-12, and IFN- $\gamma$ synthesis and release may contribute to decreased neonatal host resistance.

The addition of recombinant IL-18 to mixed mononuclear cells from adults significantly enhanced IFN- $\gamma$ production in response to GBS. The increased response to GBS induced by the added IL-18 was blocked by the addition of anti-IL-18 and partly by anti-IL-12 MAb, suggesting a role for both cytokines

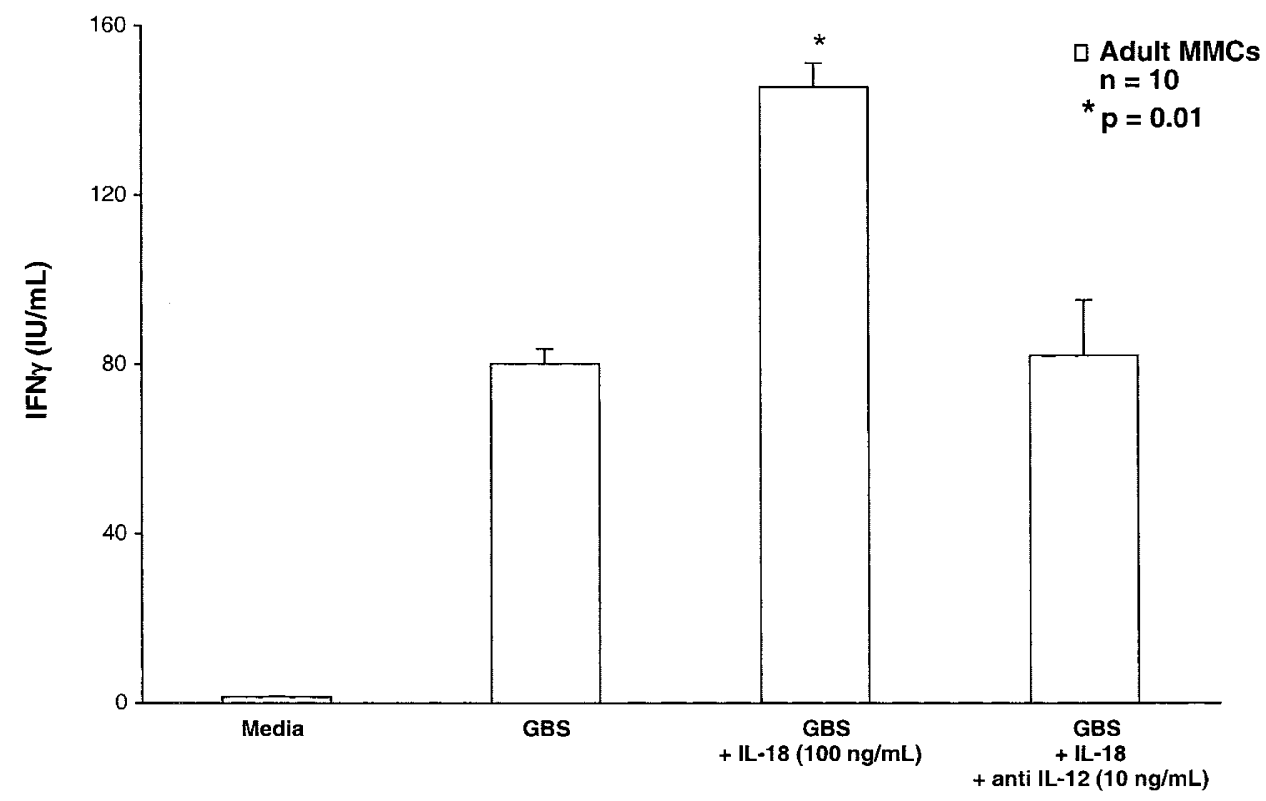

Figure 4. The effects of IL-18 (100 ng/mL) with and without anti-IL-12 antibody ( $10 \mathrm{ng} / \mathrm{mL})$ on the IFN- $\gamma$ response of adult mixed mononuclear cells to GBS after $24 \mathrm{~h}$ incubation. The addition of anti-IL-12 antibody $(10 \mathrm{ng} / \mathrm{mL})$ depresses the IFN- $\gamma$ response to IL-18 and GBS, indicating that IL-12 regulation of IL-18 influences the IFN- $\gamma$ response to GBS. No effect on IFN- $\gamma$ production was observed with recombinant IL-18 alone, as shown previously $(n=10)$, or with anti-IL-12 antibody alone (data not shown). 


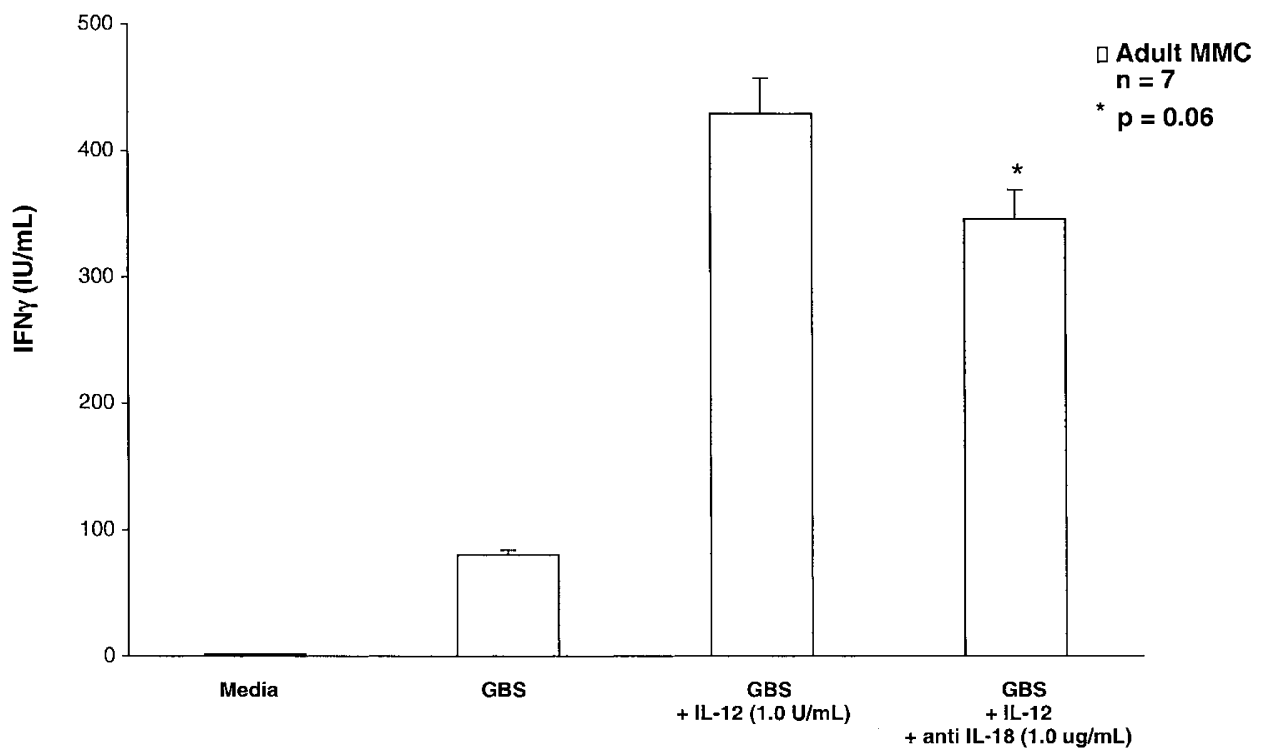

Figure 5. The effect of anti-IL-18 antibody $(1.0 \mu \mathrm{g} / \mathrm{mL})$ on IFN- $\gamma$ production by IL-12 $(1.0 \mathrm{U} / \mathrm{mL})$. The addition of IL- 18 antibody suppressed the GBS-induced IL-12 IFN- $\gamma$ response, but this decrease was not statistically significant. No effect on IFN- $\gamma$ production was observed with recombinant IL-12 alone or anti-IL-18 alone (data not shown) $(n=7)$. Incubations of the cells with GBS were carried out for $24 \mathrm{~h}$.

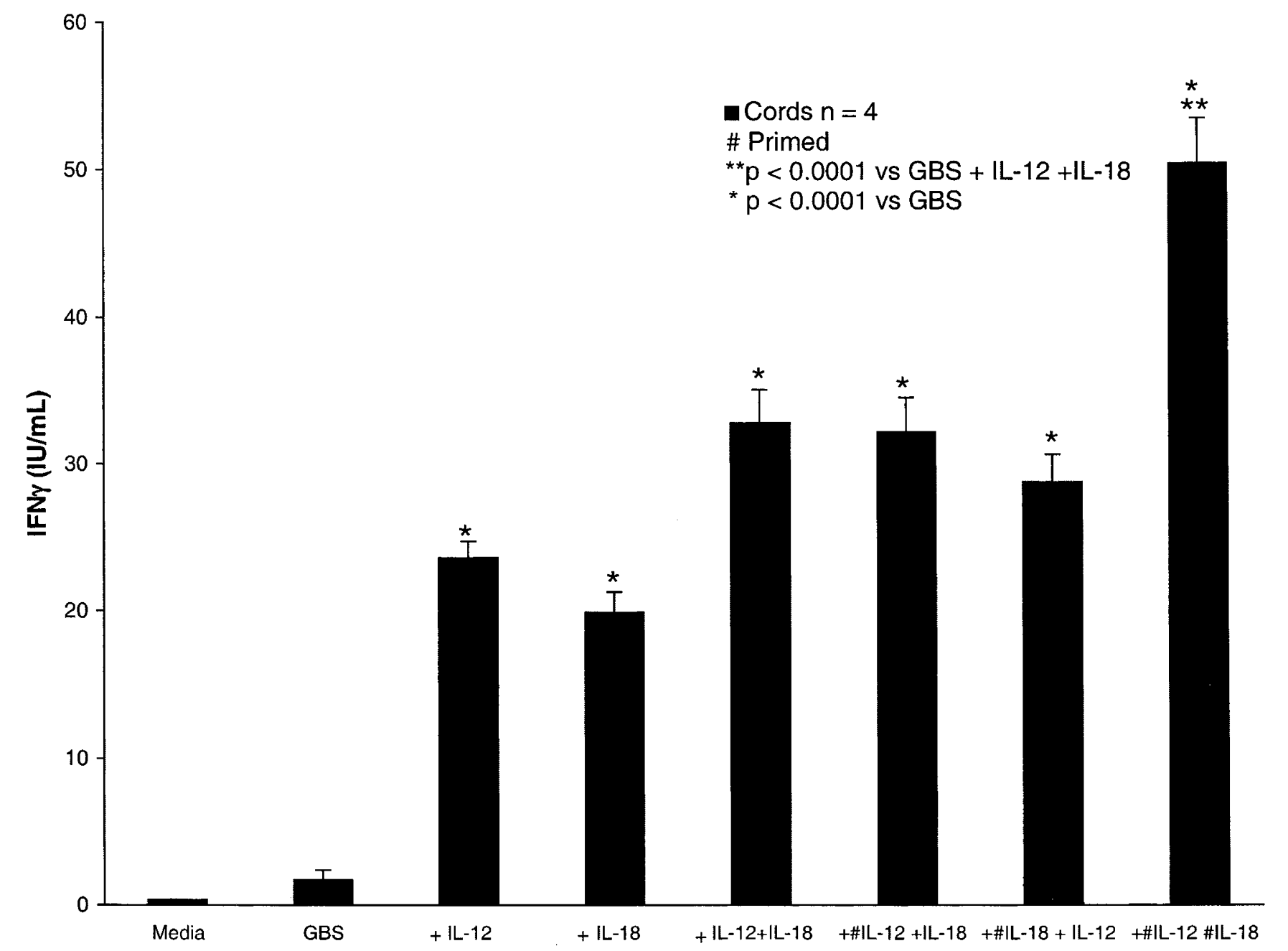

Figure 6. The effect of IL-18 (100 ng/mL) and/or IL-12 (1.0 U/mL) on IFN- $\gamma$ production by mixed mononuclear cells from cord blood with and without cytokine priming. The IFN- $\gamma$ response of the cells primed for 30 min with both IL-12 and IL-18 was significantly higher than unprimed cells or cells primed with either cytokine alone $(p<0.0001)$. Priming was carried out for 30 min before addition of GBS. Incubations of the cells with GBS $\left(1 \times 10^{6} / \mathrm{mL}\right)$ were carried out for $24 \mathrm{~h}$. 
in the enhancement of GBS-induced IFN- $\gamma$ responses by mixed mononuclear cells. Similarly, the addition of IL-18 to the mixed mononuclear cells obtained from cord blood enhanced the IFN- $\gamma$ response to GBS. This suggests that IL-18 is involved in neonatal IFN- $\gamma$ production, which has not been previously described to our knowledge.

Several recent studies have raised important questions about the relationship between IL-18 and IL-12. The combination of IL-18 and IL-12 is far more effective in the induction of IFN- $\gamma$ production than either cytokine alone, and IL-18 induces IFN- $\gamma$ only when its receptors are up-regulated by IL-12 (11, 31). In our studies, the treatment of adult mixed mononuclear cells exposed to GBS and recombinant IL-18 with anti-IL-12 significantly reduced IFN- $\gamma$ production below that of IL-18 and GBS. Treatment of adult mixed mononuclear cells exposed to GBS and recombinant IL-12 with anti-IL-18, however, did not significantly decrease the production of IFN- $\gamma$ below that of IL-12 and GBS. In addition, IFN- $\gamma$ production by adult mixed mononuclear cells exposed to GBS is stimulated by both IL-12 and IL-18, but the higher production of IFN- $\gamma$ induced by IL-18 seems to require the presence of IL-12. This suggests that IL-12 priming of IL-18-regulated IFN- $\gamma$ production is necessary for optimal IFN- $\gamma$ production in response to GBS. In our studies, priming the cord blood mixed mononuclear cells with both IL-12 and IL-18 enhances the IFN- $\gamma$ response to GBS to levels significantly above that after incubation of the GBS-stimulated cells with either cytokines alone or both together.

We have demonstrated that cells from human neonates are deficient in the ability to produce IFN- $\gamma$ in response to GBS. This deficiency may contribute to defective neonatal PMNL function and result in an increased susceptibility to infection. This IFN- $\gamma$ deficiency may be attributed in part to lymphocyte immaturity as well as depressed production of both IL-12 and IL-18, as we show here. The decreased production of the three main Th- 1 cytokines, IFN- $\gamma$, IL-12, and IL-18, likely contributes to the unique susceptibility of neonates to group B streptococcal as well as other bacterial infections.

Acknowledgments The authors thank J. Rejali for her excellent administrative and secretarial assistance.

\section{REFERENCES}

1. Okamura H, Tsutsui H, Komatsu T, Yutsudo M, Hakura A, Tanimoto T, Torigoe K, Okura T, Nukada Y, Hattori K 1995 Cloning of a new cytokine that induces IFN- $\gamma$ production by $\mathrm{T}$ cells. Nature 378:88-99

2. Munder M, Mallo M, Eichmann K, Modolell M 1998 Murine macrophages secrete interferon $\gamma$ upon combined stimulation with interleukin (IL)-12 and IL-18: a novel pathway of autocrine macrophage activation. J Exp Med 187:2103-2108

3. Stoll S, Jonuleit H, Schmidtt E, Muller G, Yamauchi H, Kurimoto M, Knop J, Enk AH 1998 Production of functional IL-18 by different subtypes of murine and human dendritic cells (DC): DC-derived IL-18 enhances IL-12 dependent Th-1 development. Eur J Immunol 28:3231-3239

4. Puren AJ, Fantuzzi G, Gu Y, Su MS, Dinarello CA 1998 Interleukin-18 (IFN- $\gamma$ inducing factor) induces IL- 8 and IL- $\beta$ via TNF $\alpha$ production from non-CD14 ${ }^{+}$ human blood mononuclear cells. J Clin Invest 1001:711-721
5. Stoll S, Muller G, Kurimoto M, Saloga J, Tanimoto T, Yamauchi H, Okamura H, Knop J, Enk AH 1997 Production of IL-18 (IFN- $\gamma$-inducing factor) messenger RNA and functional protein by murine keratinocytes. J Immunol 159:298-302

6. Olee TS, Hashimoto S, Quach J, Lotz M 1999 IL-18 is produced by articular chondrocytes and induces proinflammatory and catabolic responses. J Immunol 162:1096-1100

7. Conti B, Jahng JW, Tinti C, Son JH, John TH 1997 Induction of inteferon- $\gamma$ inducing factor in the adrenal cortex. J Biol Chem 272:2035-2037

8. Conti B, Park LC, Calingasan NY, Kim Y, Kim H, Bae Y, Gibson E, Joh TH 1999 Cultures of astrocytes and microglia express interleukin 18. Brain Res Mol Brain Res 67:46-52

9. Pizarro TT, Michie MH, Bentz A, Woraratanadharm J, Smith Jr MF, Foley E, Moskaluk CA, Bickston SJ, Cominelli F 1999 IL-18 a novel immunoregulatory cytokine, is up-regulated in Crohn's disease: expression and localization in intestinal mucosal cells. J Immunol 162:6829-6835

10. McInnes IB, Gracie JA, Leung BP, Wei X-Q, Liew FY 2000 Interleukin-18: a pleiotropic participant in chronic inflammation. Immunol Today 21:312-315

11. Dinarello CA 1999 IL-18: a Th-1-inducing, proinflammatory cytokine and new member of the IL-1 family. J Allergy Clin Immunol 103:11-24

12. Kawakami K, Qureshi MH, Zhang T, Okamura H, Kurimoto M, and Saito A 1997 IL-18 protects mice against pulmonary and disseminated infection with Cryptococcus neoformans by inducing IFN- $\gamma$ production. J Immunol 159:5528-5534

13. Wei X, Leung BP, Niedbala W, Piedrafita D, Feng G, Sweet M, Dobbie L, Smith AJH, Liew FY 1999 Altered immune responses and susceptibility to Leishmania major and Staphylococcus aureus infection in IL-18-deficient mice. J Immunol 163:2821-2828

14. Mastroeni P, Clare S, Khan S, Harrison JA, Hormaeche CE, Okamura H, Kurimoto M, Dougan G 1999 Interleukin 18 contributes to host resistance and $\gamma$ interferon production in mice infected with virulent Salmonella typhimurium. Infect Immun $67: 478-483$

15. Sugawara I, Yamada H, Kaneko H, Mizuno S, Takeda K, Akira S 1999 Role of interleukin-18 (IL-18) in mycobacterial infection in IL-18-gene-disrupted mice. Infect Immun 67:2585-2589

16. O'Garra A 1998 Cytokines induce the development of functionally heterogenous T helper cell subsets. Immunity 8:275-283

17. Magram J, Connaughton SE, Warrier RR, Carvajal DM, Wu CY, Ferrante J, Stewart C, Sarmiento U, Faherty DA, Gately MK 1996 IL-12-deficient mice are defective in IFN- $\gamma$ production and type 1 cytokine responses. Immunity 4:471-481

18. Kobayashi M, Fitz L, Ryan M, Hewick RM, Clark SC, Chan S, Loudon R, Sherman F, Perussia B, Trinchieri G 1989 Identification and purification of natural killer cell stimulatory factor (NKSF), a cytokine with multiple biologic effects on human lymphocytes. J Exp Med 170:827-845

19. Fukao T, Matsuda S, Koyasu S 2000 Synergistic effects of IL-4 and IL-18 on IL-12 dependent IFN- $\gamma$ production by dendritic cells. J Immunol 164:64-71

20. Esfandiari E, McInnes IB, Lidop G, Huang F-P, Field M, Komai-Koma M, Wei X-Q, Liew FY 2001 A proinflammatory role of IL-18 in the development of spontaneous autoimmune disease. J Immunol 167:5338-5347

21. Eriksson U, Kurrer MO, Sebald W, Brombacher F, Kopf M 2001 Dual role of IL-12/IFN- $\gamma$ axis in the development of autoimmune myocarditis: induction by IL-12 and protection by IFN- $\gamma$. J Immunol 167:5464-5469

22. Hill HR 1990 Group B streptococcal infections. In: Holmes KK, Mardh PA, Sparling PF (eds) Sexually Transmitted Diseases. McGraw-Hill, New York, pp 851-861

23. My H, Wu CT, Ku YT, Huang FY, Peng CL 1999 Group B streptococcal infection in neonates: an 11 year review. Acta Pediatr Taiwan 40:83-86

24. Kalliola S, Vuopio-Varkila J, Takala AK, Eskola J 1999 Neonatal group B streptococcal disease in Finland: a ten year nationwide study. Pediatr Infect Dis J 18:806810

25. Hemming,VG, Hall RT, Rhodes PG, Shigeoka AO, Hill HR 1976 Assessment of group B streptococcal opsonins in human and rabbit serum by neutrophil chemiluminescence. J Clin Invest 58:1379-1387

26. Sacchi F, Hill HR 1984 Defective membrane potential changes in neutrophils from human neonates. J Exp Med 160:1247-1252

27. Bryson YJ, Winter HS, Gard SE, Fischer TJ, Stiehm ER 1980 Deficiency of immune production by leukocytes of normal newborns. Cell Immunol 55:191-200

28. Wilson CB, Westall J, Johnston L, Lewis DB, Dower SK, Alpert AR 1986 Decreased production of interferon gamma by human neonatal cells. J Clin Invest 77:860-867

29. Joyner JL, Augustine NH, Taylor KA, La Pine TR, Hill HR 2000 Effects of group B streptococci on cord and adult mononuclear cell interleukin-12 and interferon- $\gamma$ mRNA accumulation and protein secretion. J Infect Dis 182:974-977

30. Hill HR, Augustine NH, Jaffee HS 1991 Human recombinant interferon- $\gamma$ enhances neonatal polymorphonuclear leukocyte activation and movement, and increases free intracellular calcium. J Exp Med 173:767-770

31. Yoshimoto T, Takeda K, Tanaka T, Ohkusu K, Kashiwamura S, Okamura H, Akira S, Nakanishi K 1998 IL-12 up-regulates IL-18 receptor expression on T cells, Th-1 cells, and B cells: synergism with IL-18 for IFN- $\gamma$ production. J Immunol 161:34003407 